\title{
Epiphytic and epipsammic diatom communities of Gölbaşı Lake (Adıyaman-Turkey)
}

\section{Gölbaşı Gölü (Adıyaman-Türkiye)'nün epifitik ve epipsammik diyatom toplulukları}

\author{
Metin Çağlar* • Güneş Pala \\ FIrat University, Faculty of Fisheries, Elazığ-Türkiye \\ *Corresponding author: firatmcaglar@gmail.com
}

How to cite this paper:

Çağlar, M. \& Pala, G. (2016). Epiphytic and epipsammic diatom communities of Gölbaşı Lake (Adıyaman-Turkey). Ege Journal of Fisheries and Aquatic Sciences, 33(3): 193-199. doi: 10.12714/egejfas.2016.33.3.02

\begin{abstract}
The present study examined certain physical and chemical parameters in epiphytic and epipsammic diatoms identified on Potamogeton perfoliatus and Chara sp. collected from an area of one square kilometers in Gölbaşı Lake located within the borders of Adıyaman city from March to October 2014.Over the course of the study, 14 taxa belonging to epiphytic diatoms and 24 taxa of epipsammic diatoms were identified. Among the epiphytic diatoms, Amphora ovalis, Diatoma vulgaris and UInaria ulna were the most significant ones in terms of abundance and individual occurrences, while among the epipsammic diatoms the most remarkable ones were Navicula salinarum, Navicula radiosa, Nitzschia linearis and Cyclotella comta with regard to abundance and individual occurrences. According to Sorensen Index the highest similarity $(78 \%)$ was found between diatoms on Potamageton perfoliatus and Chara sp. The similarity between epiphytic and epipsammic diatoms was only as high as $26 \%$ and $30 \%$. Accordingly, the macrophyte preference of diatoms as a substratum was to a large extent similar. Diatoms displayed the highest level of development in late spring and summer, when there is more light and temperatures are higher.
\end{abstract}

Keywords: Epiphitic diatoms, Epipsammic diatoms, Sorensen Similarity Index, Gölbaşı Lake, East Anatolia, Turkey

Öz: : Bu çalışmada Adıyaman il sınırları ç̧inde bulunan Gölbaşı Gölü' nden Mart- Ekim 2014 tarihleri arasında bir kilomerekarelik alandan toplanan Potamogeton perfoliatus ve Chara spp.' nin epifitik ve epipsammik diyatomeleri bazı fiziksel ve kimyasal parametreler ile birlikte araştııımıştır.

Araştırma süresince epifitik diyatomelere ait toplam 14 takson, epipsammik diyatomelere ait toplam 24 takson kaydedilmiştir. Epifitik diyatomeler içerisinde ortaya çıkıs sıkıkları ve birey sayıları ile en dikkat çeken türler Amphora ovalis, Diatoma vulgaris ve Ulnaria ulna olurken; epipsammik diyatomeler içerisinde ise ortaya çıkış sıklığı ve birey sayıları itibariyle en dikkat çeken türler Navicula salinarum, Navicula radiosa, Nitzschia linearis ve Cyclotella comta olmuştur. Potamogeton perfoliatus ve Chara sp üzerindeki diatomeler arasında Sorensen benzerlik indeksi \% 78 çıkmıştı. Epifitik ve epipsammik diyatomeler arasındaki benzerlikler ise $\% 26$ ve \% 30 gibi değerlerde çıkmışıı. Substrat olarak diatomelerin makrofitleri tercihinde büyük bir benzerlik görüldü. Diyatomeler en iyi gelişimlerini ışığın ve sıcaklığın arttığı ilkbahar sonları ile yaz aylarında göstermişlerdir.

Anahtar kelimeler: Epifitik diatome, epipsammik diatome, Sorensen benzerlik indeksi, Gölbaşı Gölü, Doğu Anadolu, Türkiye

\section{INTRODUCTION}

Human beings use water sources for a multitude of purposes including agriculture, transportation, irrigation, and consumption as food and drink. The major source of food in water is fish and other aquatic organisms. In this context, in order to develop and maintain the populations of aquatic organisms obtained from our inland waters, it is of pivotal importance to identify algae, the first link of the food chain. Producing their own food through photosynthesis, these living things constitute the first link in the food chain and are the primary producers of the aquatic environments. As they produce organic substances from inorganic ones, supply oxygen to the medium, and function as food to other consumer organisms, algae form a vital part of the life-support system in water (Ahıska and Atıcı, 2005).

Turkey has 906118 hectares of natural lakes, 18000 hectares of dam lakes, and $145000 \mathrm{~km}$ of a network of rivers. As a country rich in inland water resources and with a view to making more efficient use of these resources and turning them into sources of food and revenue, identification of algae in the aquatic environments is crucial (Çetin and Yavuz, 2001).

Aiming to identify the epiphytic diatom flora of Hazar Lake (Suluçayır Plain), Pala (2014) collected samples from Ranunculus rinoii and Ranunculus aquatilis within monthly 
periods from September 2006 to August 2007 and noted that, among the epiphytic algae, the species that were significant in terms of abundance and individual occurrences were Amphora ovalis, Synedra ulna, Cymbella affinis, and Epithemia turgida.

Studying the composition of benthic algal communities and the seasonal change in epipelic algae in Lake Uzun (Trabzon) from April 1991 to March 1993, Şahin (1998) showed that the dominant group of algae among benthic algal communities was Bacillariophyta. It is well-known that recent years have seen an increase in the number of studies (Kılınç and Sıvacı, 2000; Pala and Çağlar, 2006; Pala, 2007; Pala and Aker, 2014) about our inland waters. Besides, with the growing awareness of algae in still waters and rivers, the number of studies on these organisms also increased considerably.

The present study aims to examine the epiphytic and epipsammic diatoms and certain physical and chemical characteristics of Gölbaşı Lake in Adıyaman with a view to contributing to the identification of the algal flora of our inland waters of Turkey.

\section{MATERIALS AND METHODS}

Gölbaşı Lake positioned to the north of Gölbaşı in Adıyaman province is located between $37{ }^{\circ} 48^{\prime} 00^{\prime \prime}$ latitude and $37 \circ 38^{\prime} 48^{\prime \prime}$ longitude (Figure 1).Gölbaşı Lake is a tectonic lake and the altitude of lake is $885 \mathrm{~m}$, the lake covers a field of approximately $3 \mathrm{~km}^{2}$ (Toroglu and Toroglu, 2009).

In this study aiming to identify the epipsammic and epiphytic diatoms of Gölbaşı Lake, samples were collected from an area of $1 \mathrm{~km}^{2}$ periodically from March to October 2014

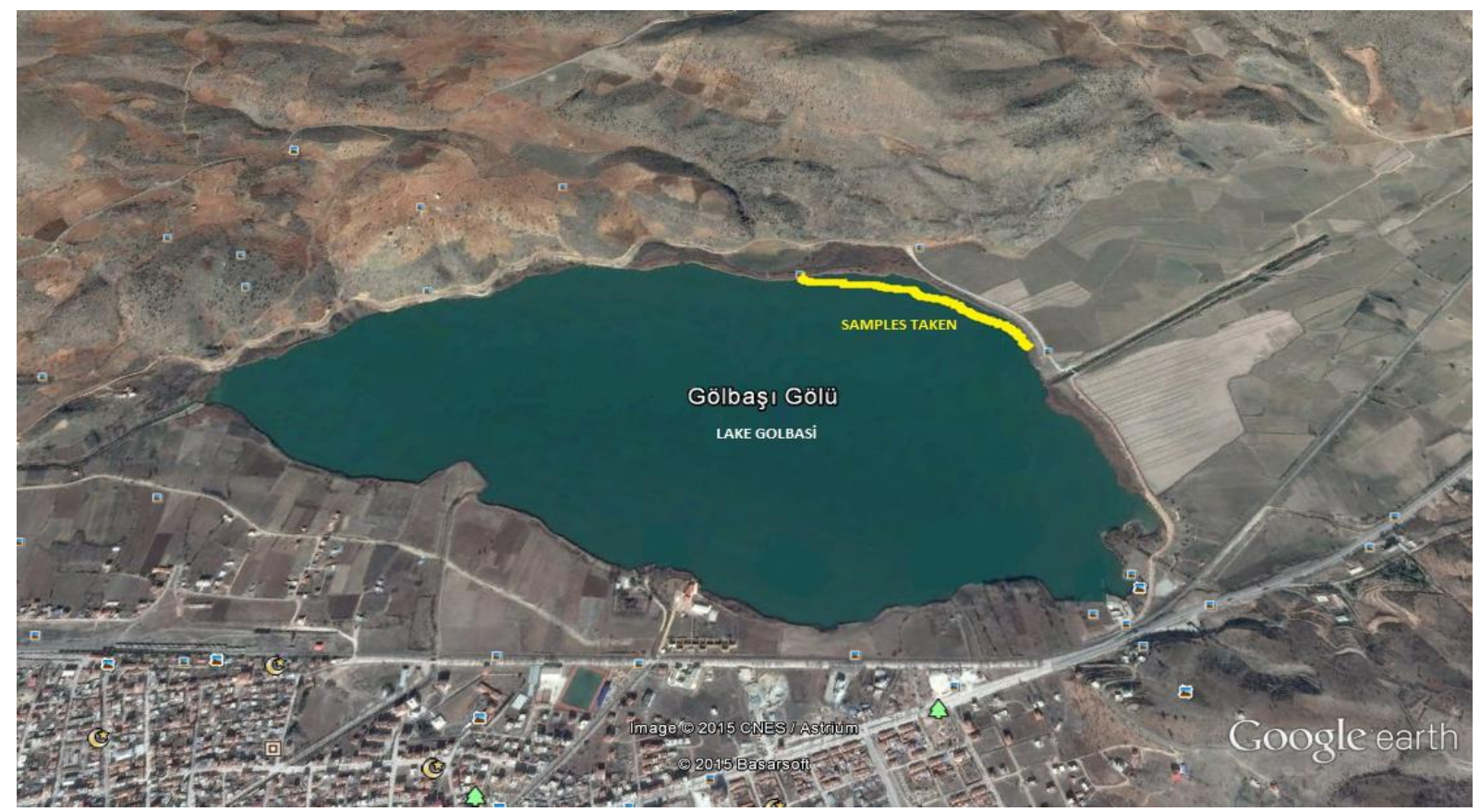

Figure 1. The Sampling area in Gölbaşı Lake (Google, 2014)

The temperature and $\mathrm{pH}$ values of the lake water were measured on the field using an Electromag brand field $\mathrm{pH}$ meter; dissolved oxygen was measured on the field using a YSI model $51 \mathrm{~B}$ field oxygen meter and hardness values of the water were analysed in the laboratory using the titrimetric method (APHA, 1985). Table 1 presents the minimum and maximum values found in these analyses. The portable devices used on the field were calibrated using stable solutions before going to the field. Cell numbers of epipsammic and epiphytic diatoms identified in per $\mathrm{ml}$ were counted according to method given in Round (1953). In order to identify the taxa of epiphytic and epipsammic diatoms, the samples were treated with $50 \%$ $\mathrm{H} 2 \mathrm{SO} 4$ and $50 \% \mathrm{NHO} 3$ and permanent preparations were obtained (Round, 1953).
Data obtained from the epiphytic and epipsammic diatoms of Gölbaşı Lake were compared using Sorensen Similarity Index (Sorensen, 1948). Relevant sources were used in the identification of taxa (Germain, 1981; Patrick and Reimer, 1966, 1975; Krammer and Lange-Bertalot, 1986, 1988, 1991a and 1991b).

\section{RESULTS}

In order to show certain physical and chemical properties of Gölbaşı Lake, surface water temperature, dissolved oxygen, $\mathrm{pH}$ and hardness values were measured in monthly periods from March to October 2014 and the results of these measurements are presented in Table 1. 
Table 1. Data from the physical and chemical analyses of Gölbaşı Lake

\begin{tabular}{|c|c|c|c|c|c|c|c|c|}
\hline & $\stackrel{\dot{\bar{\pi}}}{\sum}$ & 产 & $\sum^{\frac{\pi}{2}}$ & த் & $\dot{\Xi}$ & 官 & 远 & $\dot{\mathrm{O}}$ \\
\hline Dissolved Oxygen ( $\mathrm{mg} \mathrm{O}_{2} / \mathrm{L}$ ) & 8.0 & 8.1 & 7.8 & 6.8 & 5.9 & 5.4 & 4.3 & 5.0 \\
\hline $\mathrm{pH}$ & 7.9 & 8.0 & 8.0 & 8.4 & 7.9 & 7.8 & 8.4 & 8.7 \\
\hline Temperature $\left({ }^{\circ} \mathrm{C}\right)$ & 12.0 & 12.5 & 14.0 & 17.5 & 19.5 & 20.5 & 21.0 & 17.5 \\
\hline
\end{tabular}

Over the course of the study, as temperatures increased, a decrease was found in the dissolved oxygen values. Gölbaşı Lake was found to have the highest temperature $(210 \mathrm{C})$ in September and the lowest temperature $(120 \mathrm{C})$ in March; the highest dissolved oxygen $(8.2 \mathrm{mg} / \mathrm{L})$ in March and the lowest dissolved oxygen (4.3 mg/L) in September; the highest $\mathrm{pH}$ (8.7) in October and the lowest pH (7.8) in August (Table 1)

A total of 14 taxa of epiphytic diatoms were identified on the Potamogeton perfoliatus L. plant collected from Gölbaşı Lake (Table 2). As the Table shows, the most noteworthy taxa in terms of individual occurrences per $\mathrm{ml}$ are Diatoma vulgaris, Amphora ovalis and Ulnaria ulna. Individual occurrences of Diatoma vulgaris in May were the highest individual occurrences, while cell counts of Gomphonema olivaceum in October were the lowest individual occurrences recorded on this macrophyte (Table 2).
Based on a careful examination of Table 2, the presence of some taxa in the environment despite the absence of others or some taxa having higher abundance and individual occurrences than other taxa suggest that these diatoms make more effective use of the conditions in their environment. In other words, this can be taken as an indicator of the ability of these taxa to adapt to different living environments.

The monthly count of individual cells per $\mathrm{ml}$ of epiphytic diatoms recorded on Potamogeton perfoliatus $L$. is presented in Table2.

The epiphytic diatoms identified on Chara sp., a plant found only during 4 particular months, but not in others over the year in Gölbaşı Lake belonged to a total of 9 taxa. Ulnaria ulna, Navicula radiosa, and Diatoma vulgaris were found to have higher individual occurrences than other diatoms (Table 3)

Table 2. The monthly count of individual cells per $\mathrm{ml}$ of epiphytic diatoms recorded on Potamogeton perfoliatus

\begin{tabular}{|c|c|c|c|c|c|c|c|c|}
\hline Taxon & 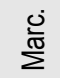 & 享 & $\stackrel{\pi}{2}^{\vec{\pi}}$ & ذ் & ફं & 宅 & 莽 & ப் \\
\hline Cyclotella ocellata Pantocksek & 11 & 17 & 19 & 13 & 10 & 9 & 7 & 5 \\
\hline Amphora ovalis Kütz. & 18 & 21 & 25 & 17 & 11 & 12 & 9 & 7 \\
\hline Cocconeispediculus Ehr. & 14 & 16 & 13 & 14 & 9 & 6 & 3 & - \\
\hline Cymbella affinis Kütz. & 17 & 19 & 18 & 16 & 12 & 8 & 5 & 2 \\
\hline Cymbella cistula (Hemp.) Kirchner & 13 & 15 & 12 & 9 & 9 & 7 & 4 & 3 \\
\hline Diatoma vulgaris Bory de Saint-Vincent & 24 & 28 & 30 & 25 & 22 & 19 & 14 & 11 \\
\hline Encyonema prostratum (Berkeley) Kütz. & 9 & 12 & 12 & 10 & 9 & 7 & 3 & - \\
\hline Gomphonema olivaceum (Hornemann) Brebisson & 13 & 15 & 14 & 12 & 7 & 5 & 3 & 1 \\
\hline Gomphonema Helveticum Brun. & 11 & 15 & 13 & 10 & 9 & 7 & 5 & 3 \\
\hline Navicula radiosa Kütz. & 17 & 17 & 20 & 18 & 12 & 10 & 6 & 4 \\
\hline Navicula tripunctata (O.F.Müll.) Bory. & 15 & 18 & 16 & 14 & 11 & 9 & 7 & 5 \\
\hline Nitzschia palea (Kütz.) W.Smith & 14 & 17 & 19 & 13 & 9 & 7 & 7 & 4 \\
\hline Nitzschia dissipata (Kütz.) Robenhorst & 10 & 15 & 14 & 8 & 10 & 5 & 2 & - \\
\hline Ulnaria ulna (Nitzsch.) P.Compere & 18 & 20 & 22 & 25 & 17 & 13 & 11 & 9 \\
\hline
\end{tabular}


Table 3. Cell numbers per ml of epiphytic diatoms recorded on Chara sp.

\begin{tabular}{|c|c|c|c|c|}
\hline Taxon & 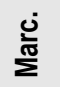 & 高 & $\mathbb{\pi}_{\Sigma}^{\vec{\pi}}$ & ఏ \\
\hline Cyclotella ocellata Pantocksek & 13 & 17 & 9 & 5 \\
\hline Amphora ovalis Kütz. & 16 & 19 & 13 & 11 \\
\hline Cymbella affinis Kütz. & 15 & 12 & 9 & 3 \\
\hline Cymbella cistula (Hemprich) O. Kirchner & 13 & 16 & 7 & 5 \\
\hline Diatoma vulgaris Bory de Saint- Vincent & 18 & 19 & 15 & 13 \\
\hline Gomphonema olivaceum ( Hornemann) Brebisson & 12 & 17 & 13 & 11 \\
\hline Navicula radiosa Kütz. & 19 & 21 & 23 & 17 \\
\hline Nitzschia palea (Kütz.) W. Smith & 15 & 17 & 14 & 13 \\
\hline Ulnaria ulna (Nitzsch.) P.Compere & 17 & 20 & 24 & 22 \\
\hline
\end{tabular}

Cell numbers per $\mathrm{ml}$ of epipsammic diatoms identified in Gölbaşı Lake are presented in Table 4. As Table 4 shows, a total of 24 taxa belonging to epipsammic diatoms were recorded in Gölbaşı Lake. The highest number of individual occurrences of epipsammic diatoms were recorded in late spring and summer.

Table 4. Cell numbers per ml of epipsammic diatoms identified in Gölbaşı Lake

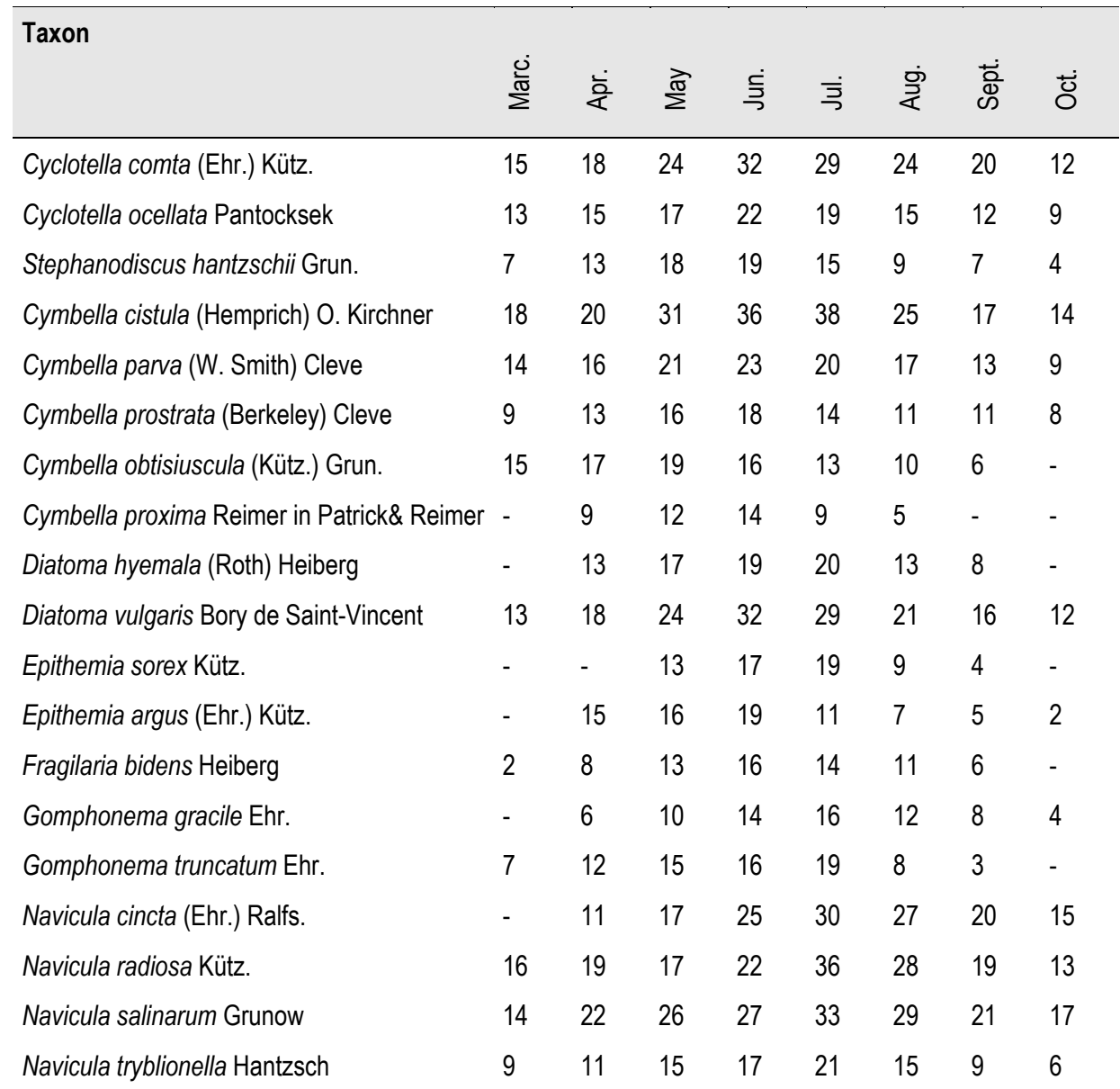




\begin{tabular}{lllllllll} 
Nitzschia linearis (Agardh) W. Smith & 11 & 22 & 36 & 39 & 29 & 20 & 19 & 9 \\
Sellaphora bacillum (Ehr.) D.G. Mann & 11 & 13 & 14 & 16 & 19 & 11 & - & - \\
Surirella robusta Ehr. & 7 & 15 & 13 & 17 & 10 & 9 & 4 & - \\
Ulnaria acus (Kütz.) M. Aboal & 5 & 15 & 14 & 12 & 11 & 7 & 2 & - \\
Ulnaria ulna (Nitzsch.) P.Compere & 16 & 25 & 37 & - & - & - & - & - \\
\hline
\end{tabular}

The similarities between epiphytic diatoms, and between epiphytic and epipsammic diatoms were analysed using
Sorensen Similarity Index (Sorensen, 1948) and the results of this analysis are presented in Table 5.

Table 5. Results of the Sorensen (Similarity) Index analysis between epiphytic diatoms on Potamogeton perfoliatus and Chara $s p$. and epipsammic diatoms

\begin{tabular}{ccc}
\hline P.perfoliatus- Chara sp. & P. perfoliatus-epipsammik & Chara sp.-epipsammik \\
\hline $78 \%$ & $26 \%$ & $30 \%$ \\
\hline
\end{tabular}

As can be seen in Table 5, the highest similarity (78\%) was found between Potamageton perfoliatus and Chara sp. The similarity between epiphytic and epipsammic diatoms was only as high as $26 \%$ and $30 \%$. Accordingly, the macrophyte preference of diatoms as a substratum was to a large extent similar.

\section{DISCUSSION}

In this study, mean values for dissolved oxygen and $\mathrm{pH}$ were found as $6.4 \mathrm{mg} / \mathrm{L}$ and 8.1 respectively. According to these findings, Gölbaşı Lake water is in class II in term of inland water quality criterion given by Uslu and Türkman (1987).

Over the course of the study a total of 14 taxa belonging to epiphytic diatoms and 24 taxa of epipsammic diatoms were recorded in Gölbaşı Lake. Since these diatoms were dominant in terms of both abundance and individual occurrences, other algae were ignored.

In this study, Cyclotella ocellata, Cymbella cistula, Diatoma vulgaris, and Ulnaria ulna were identified among both epiphytic and epipsammic diatoms. This result may indicate that these diatoms, in comparison to others, are better able to use environmental conditions to their advantage.

In the study, Cocconeis pediculus, Encyonema prostratum, Gomphonema helveticum, Navicula tripunctata and Nitzschia dissipata were found to be the only epiphytic diatoms found on Potamogeton perfoliatus plant, while Cyclotella comta, Stephanodiscus hantzschii, Cymbella parva, Cymbella prostrata, Cymbella obtisiuscula, Cymbella proxima, Diatoma hyemale, Epithemia sorex, Epithemia araus, Fragilaria bidens, Gomphonema gracile, Gomphonema truncatum, Navicula cincta, Navicula salinarum, Nitzschia linearis, Navicula tryblionella, Sellaphora bacillum, Surirella robusta and Ulnaria acus were the diatoms found only in the epipsammic flora. The presence of certain diatom taxa only in one community demonstrates that diatoms have specific incidence characteristics.

That diatoms are more significant than other groups of algae in terms of both abundance and individual occurrences, and the resulting negligence of other algae has been reported in studies conducted in lakes both in our country and abroad (Round, 1981; Temel, 1992; Pala, 2014).

In his study about algal communities in Altınapa Dam Lake and Meram Stream, Yıldız (1987) found that diatoms were dominant and abundant in comparison to other algae in both water bodies and that dominant species of epiphytic and epilitic diatoms in Altınapa Dam Lake were Synedra delicatissima, Navicula cryptocephala, Nitzschia palea, Cymbella microcephala, Cymbella amphicephala, Gomphonema olivaceum and Navicula crypcephala. This result is similar to ours in terms of identified species with the exception of Gomphonema olivaceum and Nitzschia palea.

Aiming to examine the epiphytic diatom flora of Hazar Lake (Suluçayır Düzü), Pala (2014) collected samples from Ranunculus rinoii and Ranunculus aquatilis in monthly periods from September 2006 to August 2007 and noted that, among epiphytic algae, Amphora ovalis, Synedra ulna, Cymbella affinis and Epithemia turgida were important species with regard to abundance and individual occurrences. The identification of Amphora ovalis, Cymbella affinis and Ulnaria ulna to have significant individual occurrences in our study is similar to finding of Pala (2014).

Cox (1984) emphasized that light was the major factor in the seasonal distribution of diatoms. Likewise, Round (1973) stated that diatoms grew well in spring and early summer, while their growth was lower in the period from July to October. In the same vein, Lund (1965) noted that temperature and light were main factors affecting the development of algae. In the present study, the abundance and individual occurrences of diatoms showed seasonal variations, though to a small extent. The 
species composition and individual occurrences of epipsammic diatoms were found to be the highest in spring and summer and the lowest in autumn. This result suggests that water temperature and intensity of light were effective on the propagation of diatoms.

In relation to the increase in the number of diatoms in Gölbaşı Lake over the summer, it was already reported in other studies (Stanly and Daly, 1976) that benthic algae responded very well to increased temperature and light in summer.

Round (1957) and Butcher (1946) described most diatoms to be species that are fond of alkali water. Cocconeis placentula, Cymbella ventricosa, Gomphonema parvulum and Gomphonema olivaceum, in particular, were found to be dominant organisms in alkali water. In Gölbaşı Lake, however, only Gomphonema olivaceum from among these diatoms was found, while others were not present.

Cymbella spp., Navicula spp. and Ulnaria spp. identified among the epiphytic and epipsammic diatoms in Gölbaşı Lake

\section{REFERENCES}

Ahıska, S. \& Atıcı, T. (2005). Pollution and algae of Ankara stream. Gaz University Journal of Science, 18(1): 51-59.

APHA, (1985). Standart Methods for the Examination of Water and Wastewater. American Public Health Association, Washington.

Butcher, R.W. (1946). The algal growth in certain highly calcareous streams. Journal of Ecology, 33, 268-283. doi: 10.2307/2256471

Çetin, A.K. \& Yavuz, O.G. (2001). Epipelic, epilithic and epiphytic algal flora of Cip Stream (Elazığ). Fırat University Journal of Science, 13(2): 9-14.

Chessman, B.C. (1986). Diatom flora of an Australian River system: Spatial Patterns and Environmental Relationships. Freshwater Biology, 16: 805819. doi: 10.1111/j.1365-2427.1986.tb01018.x

Cox, E.J. (1984). Observations on some benthic diatoms from North German Lakes: the effect of substratum and light regime. Verhandlungen des Internationalen Verein Limnologie, 22: 924-928.

Germain, H. (1981). Flora Des Diatomees Diatomophycees. Societye Nouvelle Des Editions Boubee, Paris

Google, (2014) Gölbaşı Lake, Adıyaman-Turkey [Retrieved, September 15 2014, from https://goo.gl/maps/]

Hutchinson, G.E. (1957). A treatise on Limnology. Vol II. Introduction to lake biology and the limnoplankton. John Wiley\& Sons, New York.

Kılınç, S. \& Sıvacı, R. (2000). A study on the past and present diatom flora of two alkaline lakes. Turkish Journal of Botany, 25: 373-378.

Krammer, K. \& Lange-Bertalot, H. (1986). Bacillariophyceae. I. Teil: Naviculaceae in Ettl, H., Gerloff, J., Heynig, H. and Mollenhauer, D. (eds) Süsswasser flora von Mitteleuropa, Band 2/1. Gustav Fischer Verlag: Stuttgart, New York, 876p.

Krammer, K. \& Lange-Bertalot, H. (1988). Bacillariophyceae. II. Teil: Bacillariaceae, Epithemiaceae, Surirellaceae in Ettl, H., Gerloff, J. Heynig, H. and Mollenhauer, D. (eds) Süsswasser flora von Mitteleuropa, Band 2/2. VEB Gustav Fischer Verlag: Jena. 596p.

Krammer, K. \& Lange-Bertalot, H. (1991a). Bacillariophyceae. III. Teil: Centrales, Fragilariaceae, Eunotiaceae, in Ettl, H., Gerloff, J., Heynig, H. and Mollenhauer, D. (eds) Süsswasser flora von Mitteleuropa, Band 2/3. Gustav Fischer Verlag: Jena. 576p.

Krammer, K. \& Lange-Bertalot, H. (1991b). Bacillariophyceae. IV Teil:Achnanthaceae, Kritische Erganzungen zu Navicula (Lineolatae) und were usually reported to be the typical benthic species of inland waters (Hutchinson, 1957).

Chessman (1986) noted that Navicula and Nitzschia were cosmopolite species. The identification of Navicula and Nitzschia in both the epiphytic and epipsammic flora in our study lends support to result of Chessman (1986).

As the studies summarized above show, the dominant organisms in the lakes are diatoms. This dominance can be interpreted as an indication that, when compared to other groups of algae, diatoms make better use of the conditions in freshwater. The present study aims to examine the epiphytic and epipsammic diatoms and certain physical and chemical characteristics of Gölbaşı Lake in Adıyaman with a view to contributing to the identification of the algal flora of inland waters in Türkiye.

In consideration of the continuous presence of diatoms in the epiphytic and epipsammic algal groups, it can be concluded that diatoms are cosmopolitic algae that are found on all substrata.

Gomphonema, Gesamtliteraturverzeiichnis Teil I-IV. in Ettl, H., Gerloff, J., Heynig, H. and Mollenhauer, D. (eds) Süsswasser flora von Mitteleuropa, Band 2/4. Gustav Fischer Verlag: Jena. 437p.

Lund, J.W.G., (1965). The Ecology of the Freshwater Phytoplankton, Biological Reviews. 40, 231-293. doi: 10.1111/j.1469-185X.1965.tb00803.x

Pala, G. \& Aker, E. (2014). The Investigation of planktonic and benthic algae in Pınarbaşı (Elbistan/ Kahramanmaraş). Fırat University Journal of Science. 26(2), 105-113

Pala, G. \& Çağlar, M. (2006). Epilithic diatoms in Keban Dam Lake and their seasonal variations. Firat Universty Journal of Science. 18 (3), 323-329.

Pala, G. (2007). The planktonic algae and their seasonal variations in Gülüşkür Region of Keban Dam Lake II- Bacillariophyta. FIrat University Journal of Science. 19 (1), 23-32.

Pala, G. (2014). Epiphytic diatom flora of Hazar Lake (Suluçayır Düzü). Fırat University Journal of Science. 26 (1), 45-54.

Patrick, R. \& Reimer, C.W. (1966). The Diatoms of the United States, Exclusive of Alaska and Haxaii. Monographs of the Academy of national sciences of Philadelphia no: 13. Pennsylvania, USA, 688p.

Patrick, R. \& Reimer, C.W., (1975). The Diatoms of the United States. Volume II. Acad. Sci Philadelphia.

Round, F.E. (1953). An investigation of two benthic algal communities in Malharm Tarn, Yorkshire, Journal of Ecology, 41, 97-174. doi: $10.2307 / 2257108$

Round, F.E. (1957). Studies of the English Lake District Part II. The distribution of Bacillariophyceae on the sediments. Journal of Ecology, 45, 343-360. doi: $10.2307 / 2256951$

Round, F.E. (1973). The Biology of the Algae, Edward Arnold, London.

Round, F.E. (1981). The Ecology of algae, Cambridge University press, USA, $653 p$.

Sorensen, T. (1948). A method of establishing groups of equal amplitude in plant sociology based on similarity of species and its application to analyses of the vegetation on Danish commons. Kongelige Danske Videnskabernes Selskab, 5(4): 1-34.

Stanly, D.A., \& Daly, R.J. (1976). Environmental control of primary productivity in Alaskan Tundra Ponds. Ecology, 57, 1025-1033. doi: 10.2307/1941067 
Şahin, B. (1998). Benthic algae flora of Sera Creek (Trabzon), XIV. National Biology Congress, 7-10 September, Samsun, II, 272-281.

Temel, M. (1992). Phytoplankton of Sapanca Lake, Turkish Journal of Aquatic Sciences, 1, 25-40.

Toroglu, E. \& Toroglu, S. (2009). Microbial pollution of water in Golbasi Lake in Adiyaman, Turkey. Journal of Environmental Biology, 30(1), 33-38.
Uslu, O. \& Türkman, A. (1987). Water Pollution and Control. Prime Ministry General Directorate of Environment Publications Educations Series,364p, Ankara.

Yıldız, K. (1987). A study on algal communities of Altınapa Dam Lake and Meram Stream. Cumhuriyet Science Journal, (5), 191-207. 